\title{
THE GENUS CHRISTENSONIA HAAGER
}

\author{
ERIC A. CHRISTENSON \\ 1646 Oak Street, Sarasota, Florida 34236, U.S.A.
}

\begin{abstract}
The monotypic Vietnamese genus Christensonia Haager is discussed and illustrated by a detailed line drawing. A warm-growing, lowland plant, $C$. vietnamica is an exciting addition to the tropical horticulture as well as a taxonomic bridge between the genera Aerides, Rhynchostylis, and Vanda.

RESUMEN. Se discute y se ilustra con un dibujo de plumilla detallado el género monotípico vietnamita Christensonia Haager. Una planta de clima cálido, nativa de tierras bajas, C. vietnamica es un interesante aporte a la horticultura tropical, así como un puente taxonómico entre los géneros Aerides, Rhynchostylis y Vanda.
\end{abstract}

Key Words: Orchidaceae, Aeridinae, Christensonia, Christensonia vietnamica, Vietnam

In 1993 Czech botanist Jiri (George) Haager kindly honored me by describing a new genus of Vietnamese orchids Christensonia (Haager 1993). In that account and later mention of the genus (Christenson 1996), space consideration did not allow publication of an excellent line drawing of the type plant by Haager. This article rectifies this situation.

A member of the subtribe Aeridinae (synonym: Sarcanthinae), Christensonia exhibits a mosaic of characters found in the closely related genera Aerides Loureiro, Rhynchostylis Blume, and Vanda Jones.

Christensonia differs from Aerides by having no column foot. And unlike most species of Aerides, the lip of Christensonia is not flexibly hinged below the lateral lobes allowing deflexion of the lip by pollinators. Christensonia is similar to Rhynchostylis, especially in having a narrowly linear stipe to the pollinarium, but differs by having a clearly three-lobed lip. In addition, plants of Christensonia are miniature and few-flowered compared with Rhynchostylis.

Christensonia is perhaps most similar to Vanda. In particular, Christensonia shares two characteristics with Vanda. First, the spurs are straight and in the same plane as the midlobe of the lip. Second, the only flexible portion of the lip is the base of the midlobe.
The green and white flowers of Christensonia are unlike the generally white and rose-purple patterns seen in Aerides and Rhynchostylis. However, they are similat to some species of Vanda, especially those of Vanda section Cristatae Lindley which are sometimes segregated as the genus Trudelia Garay (q.v., Christenson 1994). Nothing is known of the pollinaton biology of Christensonia nor the significance, if any, of the green and white floral coloration.

Plants of Christensonia have entered horticulture and are readily available commercially in the United States. A plant cultivated in Sarasota, Florida, for several years has proven to be vigorous and trouble-free to grow. Its first flowering was on a plant of the similar size to the one shown in the drawing. Plants in the Czech Republic and the United States flower in july. Its flowering season in nature is unknown.

Christensonia vietnamica J.R. Haager, Orchid Digest 57(1): 40. 1993.

TYPE. Southern Vietnam, Prov. Khanh Hoa, Ninh Tay village, $100 \mathrm{~m}$, April 1989, collected by O. Dubec and J. Jurak, flowered in cultivation in Prague, PR 11392 (holotype, PR). FIG. 1.

Monopodial epiphytes. Stems to $30 \mathrm{~cm}$ long. Leaves strap-shaped, erose at apex, to $6 \times 1 \mathrm{~cm}$. 


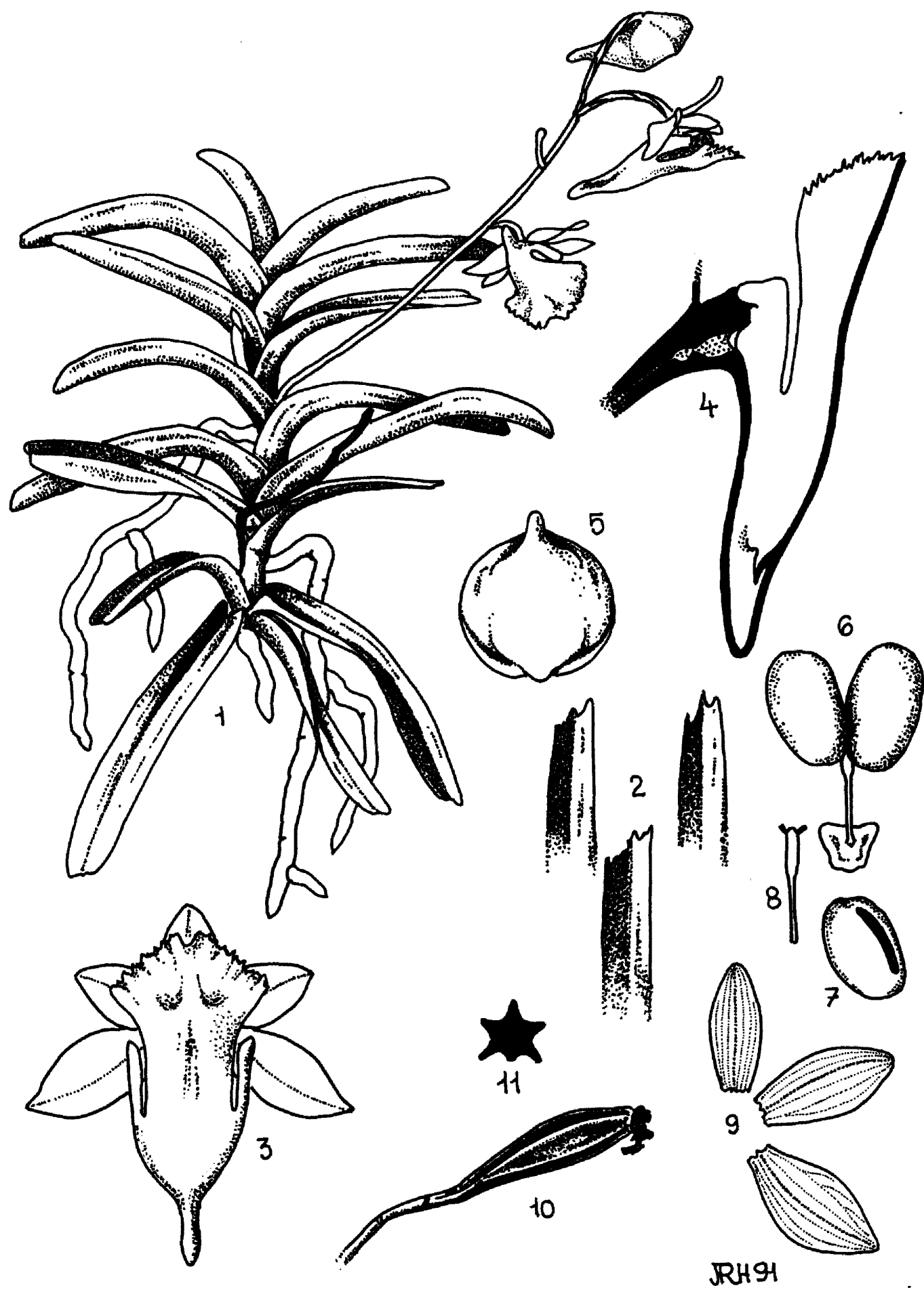

Figure 1. Christensonia vietnamica J.R. Haager. 1. Habit. 2. Leaf apices. 3. Flower from below. 4. Longitudinal section of the lip. 5. Anther. 6. Pollinarium. 7. Pollinium. 8. Stipe. 9. Sepals and petal. 10. Fruit. 11. Cross-section of the ovary. Drawing of the type plant by Juri Haager. 
Inflorescences 1-3, erect, few-flowered, to $8 \mathrm{~cm}$ long. Flowers 3-5, resupinate, somewhat nodding, the sepals, petals and lateral lobes of the lip yellowgreen, the midlobe of the lip white. Sepals and petals subequal, to $1.6 \times 0.7 \mathrm{~cm}$, the dorsal sepal oblong-elliptic, obtuse, convex, the lateral sepals obliquely elliptic-obovate, obtuse, convex, the petals elliptic, obtuse, somewhat incurved. Lip three-lobed, to $3.4 \mathrm{~cm}$ long from the apex of the spur to the apex of the midlobe, the lateral lobes rectangular, obtuse, to $0.7 \times 0.3 \mathrm{~cm}$, the midlobe fan-shaped with a broad claw, with finely toothed and undulate margins, to $1.8 \times 1.6 \mathrm{~cm}$, the spur with small, scale-like, internal glandular processes below the apex. Column very short, to $0.3 \mathrm{~cm}$ long. Pedicel and ovary six-winged, twisted.

ACKNOWLEDGEMENTS. I graciously thank Jĭri Haager for honoring me with this commemoration and for lending the accompanying illustration for this article.

\section{LITERATURE CITED}

Christenson, E.A. 1994. Taxonomy of the Aeridinae with an infrageneric classification of Vanda Jones ex R. Br. Proc. 14th World Orch. Conf. 206-216. 1996. Sarcanthinae genera 22: Christensonia. Orchids 65(3): 282-283.

Haager, J.R. 1993. Some new taxa of orchids from Southern Vietnam. Orchid Digest 57(1): 39-44. 